This item was submitted to Loughborough's Research Repository by the author.

Items in Figshare are protected by copyright, with all rights reserved, unless otherwise indicated.

\title{
The Soviet pavilion at Expo 58 and the search for a modern socialist style
}

\section{PLEASE CITE THE PUBLISHED VERSION}

https://www.routledge.com/A-History-of-Russian-Exposition-and-Festival-Architecture-1700-2014/AronovaOrtenberg/p/book/9781138207554

\section{PUBLISHER}

Routledge (c) The Author

\section{VERSION}

AM (Accepted Manuscript)

\section{PUBLISHER STATEMENT}

This is an Accepted Manuscript of a book chapter published by Routledge in A History of Russian Exposition and Festival Architecture: 1700-2014 on 4 September 2018, available online: http://www.routledge.com/9781138207554.

\section{LICENCE}

CC BY-NC-ND 4.0

\section{REPOSITORY RECORD}

Reid, Susan. 2018. "The Soviet Pavilion at Expo 58 and the Search for a Modern Socialist Style". figshare. https://hdl.handle.net/2134/36432. 
Chapter for Alla Aronova and Alexander Ortenberg, eds,

Measuring up Against the West:

A History of Russian Exposition and Festival Architecture

Susan E. Reid s.e.reid@lboro.ac.uk

\section{The Soviet Pavilion at Expo '58 and the search for a modern socialist style}

The first World Fair of the Cold War era, Expo '58, was held in Brussels 17 April19 October 1958. ${ }^{1}$ Possibilities for peaceful encounters between the two opposed global systems of Capitalism and Communism had begun to grow, as the process of destalinization was extended to international relations and a new course, "peaceful coexistence," was adopted in the mid-1950s. This placed greater emphasis on "cultural offensive," diplomacy, and exchange, and on economic and technological competition, as expressed in repeated pledges to "catch up and overtake the West". ${ }^{2}$ Expo '58, according to the Belgian organizers, had a vital and urgent mission to improve Cold War international relations by cultural means. 3 Seeking to engender dialogue, reconciliation and rapprochement between the two camps, the first Cold War World Fair would create a "crossroads of the nations," reduce tensions and reveal a common humanity. The fair's Director General, Baron Mons de Fernig, declared: "each nation will show its own conception of happiness and the path towards achieving it.". 4 Pursuing the Enlightenment goals of progress and happiness common to both East and West, the Expo was be an international expression of the "New Humanism," proclaiming the optimistic narrative that scientific and technological progress would improve human life. At the same time, World Fairs were a continuation of war by other means. ${ }^{5}$ The shadow of World War II, the Cold War, and mutual atomic destruction loomed over Expo 58. Cold War competition would be waged under slogans that emphasised peaceful uses of the atom and scientific and technological progress in service of human happiness: "for a more human world, science and technological progress in service of humanity". ${ }^{6}$ The principles of peaceful coexistence and peaceful competition 
between the "two camps" were fought out over competing definitions of progress, modernity and "humanism." ?

Among the media used at Brussels to wage Cold War by peaceful means, a central place was taken by architecture and virtuoso displays of cutting-edge structural engineering. ${ }^{8}$ In this regard, Brussels continued the tradition of World Fairs as both celebrations and instruments of technological, economic, and social progress. The great fairs of the nineteenth-century had already established two dominant models through which to proclaim the message of progress: the Crystal Palace and the Eiffel tower, the former horizontal, transparent, and apparently dematerialized, the latter a vertical statement of engineering's conquest of gravity. ${ }^{9}$ The politicization of modern architecture in the midtwentieth-century, vividly expressed at the Paris 1937 World Fair in the confrontation between the pavilions of National Socialist Germany and the USSR, continued at the first postwar fair in 1958. Soviet architect Georgii Gradov, reporting on the Expo for his colleagues in the architectural establishment, dubbed it the "Brussels architectural festival."10 Members of the team that designed the USSR pavilion also observed that, "the most interesting exhibits are the pavilions themselves". ${ }^{11}$ Pavilions served not only to house the exhibitions, but as means of communication in their own right. As Umberto Eco wrote in the context of the 1967 Montreal World Fair (but no less applicable to Expo 58), "In an exposition, architecture proves to be message first, then utility; meaning first, then stimulus. [...W]e show not the objects but the exposition itself." 12 Architecture and structural engineering, along with innovative exhibition display techniques, were used by many nations at Brussels as a visceral medium of mass communication, expressing in various ways the key values of Cold War peaceful competition--modernity, social and technological progress, democracy, humanity, and peace-and defining their vision of a better future for all in terms of command of the possibilities offered by new technologies, structures and materials. $^{13}$

This chapter focuses on the design of the USSR pavilion for Brussels and the meanings it was intended to convey both at home and abroad. The World Fair represented an important opportunity for the post-Stalin USSR to engage in the "cultural offensive," to propagate abroad an image of a peaceful, humane, 
democratic and scientifically advanced Soviet Union, and to demonstrate--not only to the capitalist West but also to the decolonizing world--the superiority of socialism as a means to social, scientific and technological progress, prosperity and human happiness. The USSR pavilion took shape and was understood within a whole web of dialogues and relationships, diachronic and synchronic, domestic and international, architectural and ideological, both within the socialist bloc and across the Iron Curtain. ${ }^{14}$ The multiple and intersecting conditions of production and reception of the Soviet architectural self-image, as presented to the world at Brussels, included both the broad context of shifting Cold War international relations and the specific context of the fair: the symbolic geometry of the exposition territory, as established by the Belgian Expo committee; the real and imagined ways that its neighbours on the site, notably the USA, would present themselves; the umbrella theme of scientific optimism and a new humanism, to which all participants were obliged to refer; and the anticipated agendas and responses of the viewing public. ${ }^{15}$ At the same time, changes under way back home in the USSR-destalinization in the realms of politics, culture and architecture--informed the contemporary meanings and historical significance of the Soviet pavilion design. The period during which the pavilion and displays were conceived (between June 1956 and the opening of the Expo on 17 April 1958) were characterized by political upheaval, destalinization and cultural "thaw," including a reexamination of received practices and models of the recent Stalinist past, a search for a usable past and for new ways forward. I aim to place the pavilion in relation to some of the developments back home as well as in the international context of Cold War competition, as represented at Brussels.

\section{The Expo}

Notwithstanding the conciliatory rhetoric of peace, coexistence, and common humanity, the self-representations and encounters at the fair were unavoidably framed in terms of the Cold War's systemic conflict, ideological difference, and competition between the two camps of socialism and capitalism. Thus the USSR pavilion was to communicate the idea of happiness in the land of the Soviets and the socialist path towards it: the historical trajectory mapped out by MarxismLeninism, which was to be achieved through state planning and Party guidance, education, industrialization and scientific and technological progress. Even the 
rhetoric of peace was a matter of Cold War competition. While Eisenhower conducted his Peace Offensive, the Soviet Union claimed for itself the role of world peace-maker and protector of the weak and vulnerable--such as the fledgling nations just shaking off the yoke of imperialism and colonialism-from the "imperialist warmongering capitalist camp". ${ }^{16}$ Placing the confrontation and comparison between the new postwar superpowers--the USA and USSR--at the centre of attention, the fair dramatized the new world order with its abstract binary antinomies, just as, in 1937, the Paris World Fair had showcased the confrontation between Stalin's USSR and Nazi Germany in the face-off between Boris Iofan's and Albert Speer's pavilions, discussed in Chapter 8 by Danilo Udovički-Selb. Architecture was, once again, to play an important part in reinforcing the new, postwar balance of power in Western minds. ${ }^{17}$

<Fig. 1: General plan of the exposition, Arkhitektura SSSR no. 2 (1957): 44.>

The Belgian exhibition committee sought to engineer the postwar superpowers into peaceful coexistence by assigning the USA and USSR adjacent lots in the northern part of the exhibition ground in the same triangular site. ${ }^{18}$ Contiguity would, they hoped, compel them to engage in dialogue, while making it inevitable that visitors to the fair would directly compare them. The size of the territories allotted to the superpowers, two of the largest national sectors in the whole fair, also pitted them directly against one another as equal but opposing world powers. ${ }^{19}$

However, the battle of titans was staged on an uneven field--literally; the US sector lay on higher ground above the Soviet one. Historian of the Brussels fair Rika Devos has analysed an amusing sketch by the architect of the US pavilion Edward Durell Stone, which personifies the close encounter between the US and USSR in stereotypical figures. The American, relaxed, at ease, and modern, looks down from above on his Russian neighbour below, caricatured as a Cossack in traditional dress, in pugnacious pose, sword drawn. ${ }^{20}$ The idea of unconstrained ease and natural superiority underpinned the design of the American pavilion and its contents, which deliberately eschewed bragging about US prosperity. The Soviet Union, by contrast, was expected to appear at the fair as belligerent and un-modern. ${ }^{21}$ 
There were some grounds for the American confidence humorously expressed in Stone's sketch. The USSR was at a disadvantage not only because of its lower ground, but because the fair took place on Western European turf, where the viewing public could be expected to be predominantly Western subjects, whose worldview and preconceptions were shaped by capitalist ideology. Despite the rhetoric of mutual understanding and coexistence, reconciliation was to take place on terms set by the West, with the Soviet Union playing "catch-up". ${ }^{22}$ Moreover, the host country, Belgium, was an ally of the USA and beneficiary of Marshall Aid. The Belgian government-appointed organizers of the World Fair actively courted the USA's participation and kept the US government abreast of Soviet plans throughout, thus placing the Soviet planners at a disadvantage. ${ }^{23}$

The USSR Council of Ministers formally accepted the invitation to participate in the Brussels fair on 6 June 1956. ${ }^{24}$ A number of state committees, departments and ministries were charged with preparing for this major propaganda campaign, notably the All-Union Chamber of Commerce and the State Committee for Cultural Links with Foreign Countries (1957-67). ${ }^{25}$ The design and construction of the pavilion were entrusted to the State Committee for Construction Affairs under the USSR Council of Ministers, GOSSTROI. In July 1956, GOSSTROI SSSR, together with the USSR Chamber of Commerce, announced a closed competition for the design of the USSR pavilion, for which leading design organizations developed projects. ${ }^{26}$

The Soviet planners recognized from the start both the covert aims of waging Cold War soft warfare and the uneven playing field. Although Brussels was officially defined as a universal exposition, they had no doubt that the capitalist sectors would treat it as an arena for ideological competition and struggle between the socialist and capitalist systems. ${ }^{27}$ The efforts of all the western pavilions, Soviet intelligence established, would lie in the realm of ideology, values, and meanings, demonstrating "not what they produce, but what they represent." 28 Therefore the Soviet Union must use every aspect of its presence at the Expo--the architecture of the pavilion, the displays it contained, the accompanying advertising and propaganda campaign, and the programme of performances and events--to engage in ideological battle for the socialist way of 
life. The Soviet pavilion must tell a story that inflected the fair's "humanist" umbrella theme with a system-specific slant. ${ }^{29}$ With nearly fifty states expected to participate, and with an anticipated footfall of 35-50 million viewers, Brussels represented an unprecedented and unmissable opportunity for the USSR to propagandize openly in the West. 30

The Soviet domestic context: destalinization, including in architecture

The specific conditions of Brussels, the contiguity of the US and USSR pavilions, and the anticipated comparison with the USA helped shape the Soviet conception of its pavilion and displays. ${ }^{31}$ At the same time, the design for the Brussels pavilion, along with its contemporary meanings and references, were also shaped by political and cultural conditions at home.

The year 1956--during which the Soviet government (after some prevarication in 1954-55) took the decision to participate in the World Fair and the competition for the design of the USSR pavilion took place--was a momentous one in Soviet politics at home and across the socialist bloc. In February 1956 First Secretary Nikita Khrushchev delivered his "Secret Speech" in which he denounced Stalin's personality cult and the "excesses" of his regime. ${ }^{32}$ The First Secretary had already condemned the "excesses" in architecture committed in Stalin's name over a year earlier; in a programmatic speech to the concluding plenary of the so-called "Builders' Conference" held 30 November-7 December 1954, Khrushchev called on architects to abandon the "extravagance and superfluities" and historicism of the late Stalinist "triumphal style". 33 The core ideas and much of the substantiating detail reflected the influence of a modernizing faction in the architectural establishment, allegedly led by Gradov, who would later become head of the Research and Design Institute for Industrial Buildings in Moscow. ${ }^{34}$ Accusing architects of wasting the people's money on one-off designs for monumental edifices, encrusted with historicist ornament, Khrushchev called for Soviet architects to develop costeffective, standardized building types and type plans, and to utilize the latest construction technology and man-made materials. Amongst the most egregious excesses of irrational ostentation and waste he identified were towers and decorative turrets, exemplified by the ring of high buildings for postwar Moscow. "We must not get carried away with architectural decoration or aesthetic 
embellishment, nor should we crown our buildings with completely unjustified towers and sculptures. We are not against beauty, but we are against superfluity." While towers and turrets served symbolic purposes, as gestures of triumph and domination, they had little utilitarian function, were expensive to build and maintain, and they lost heat energy. This was "space to be looked at only; it is not for living or working in." 35 Thus, repudiating the legacy of the recent past, Khrushchev announced a new rationalist line in Soviet architecture; it was now to be subordinated to the needs of society and to progressive building technology and engineering. Architects must descend from their ivory towers and become builders. ${ }^{36}$

In combination with the more conciliatory foreign policy of peaceful coexistence, Khrushchev's intervention also spelled a move away from Stalinist architecture's anti-modernism, isolationism, and orientation towards the premodern Russian past, especially during the postwar "anti-cosmopolitan" campaign that accompanied the onset of Cold War. ${ }^{37}$ Soviet architects were now to re-engage with, and learn from, the international community of architects and engineers: "to use everything from foreign experience that has value in technical and architectural respects." 38 Western innovations in structural engineering and materials (conveniently assumed to transcend ideological divisions), such as precast concrete, prefabrication and space frames, were to support the modernization and industrialization of Soviet construction. Khrushchev also indicated that the blanket rejection of Russian Constructivism, condemned for formalism under Stalin, had gone too far, indicating that it could now be cautiously and selectively re-examined in search of new, functional design principles. $^{39}$

While the destalinization of architecture placed emphasis on developing standard designs for industrial, prefabricated construction of mass housing, a number of flagship projects for individual representative public buildings were also launched to develop the new Soviet architecture, exemplify the use of new methods and materials, and (as the Second Congress of Soviet Architects in November 1955 exhorted Soviet architects), to "master the method of socialist realism in a contemporary way". 40 The pavilion for Brussels was one of the earliest of these high-profile, one-off projects through which a contemporary, 
post-Stalinist architecture was formulated. In the period coinciding with the design, construction and reception of the Brussels pavilion, 1956-58, other flagship projects included competitions for several important projects for Moscow: a new pavilion for the Permanent Construction Exhibition, held in 1956; the revived project of the Palace of Soviets project, held in two rounds 1957-59; and the Moscow Pioneer Palace, constructed 1958-62.41 This was largely paper architecture; only the Brussels pavilion and the Pioneer Palace were realized. But even the hypothetical designs, as well as the competition briefs and the process of design and critique, played a part in the process of defining the parameters of the Soviet Union's new architectural image.

Much was at stake in the competition for the Soviet pavilion for Expo '58. Not only was this one of the earliest post-Stalin projects for an individual public building, where the demands of the new Soviet architecture began to be worked out; it was also the first commission for an international project following the adoption of the new foreign policy line of peaceful coexistence and the new architectural line announced by Khrushchev's repudiation of Stalinist excesses. It was charged with finding a new image to represent the Soviet Union to the world as a modern global superpower and leader in technological progress "democratism" and socialism. Thus it was to be the first declaration of the Soviet Union's new self-identity as a modern, outward looking, technological power, and an assertion of its parity as a world power with global reach and with world leading technology, nuclear capacity and aspirations to space conquest. The competition entries and jury's choice were expected to give an indication of the new course, elaborating in practice the implications of Khrushchev's intervention for a Soviet architectural identity and the parameters of a modern Soviet architectural style, a contemporary form of socialist realism.

Twenty-one projects were submitted to GOSSTROI's closed competition for the Brussels pavilion, of which six were shortlisted for further work. A public viewing of the competition entries was organized by the USSR Union of Architects in Moscow in November 1956 (the month that had begun inauspiciously with the Hungarian revolution and its suppression), forming the basis for a wide-ranging discussion of the parameters of the new architecture. ${ }^{42}$ Many architects and engineers took part in the discussion, ensuring its continued 
impact on other projects over the next few years. First prize and the commission to build the pavilion in Brussels were awarded to a project designed by a relatively young collective from the Moscow Architectural Studio of the Ministry of Construction: Iurii Abramov, Anatolii Polianskii, Andrei Boretskii, V. Dubov, and engineers Iurii Ratskevich and Kseniia Vasil'eva. ${ }^{43}$ Work on site to prepare the foundations began in December 1956. ${ }^{44}$

We turn now to look more closely at the competition brief for the Brussels pavilion design and the paradigm shift it implied. The remainder of this chapter will then consider the anticipated context within which it was expected to operate at Brussels--notably its juxtaposition with the US sector; and the way in which the winning competition design engaged with the challenges. Finally, it examines briefly some competing visions of the pavilion. The Brussels pavilion took shape in conversation with a small number of other landmark projects in the second half of the 1950s, as well as with historical precedents, especially in the genre of exhibition pavilion but also of the "people's palace". Regrettably however these lie beyond the scope of this short essay.

The brief: a palatial tent

The competition brief for the Brussels pavilion, issued in July 1956, called for a design "whose architectural image reflects the greatness and power of the Soviet Union and demonstrates the capacities of the Soviet construction industry." 45 It demanded a single unified volume as the means to express the requirede sense of grandeur and power. To represent the Soviet Union's industrial and technological progress and demonstrate its leading position in construction technology and engineering, the competing design bureaux were explicitly instructed to design structures that were contemporary and technologically advanced. The interior must be arranged to facilitate convenient viewing of the whole exhibition, with all the spaces interconnected. The pavilion had to include, in addition to the main exposition halls, rooms for "cultural-mass work" (educational/mediation activities), a 1000-seat cinema-concert hall; a café; and back-spaces for administration, housekeeping, storage, etcetera. Functional efficiency and services were accorded great importance, including air conditioning, water and electricity supply, and communications. ${ }^{46}$ 
An especially challenging aspect of the brief was that when the fair was struck the Soviet pavilion was to be dismantled and transported back to Moscow where it would be reassembled at the Permanent All-Union Exhibition of Construction and Architecture on the Frunze Embankment, with adaptations such as secondary glazing, heating and thermo-insulation necessary for a permanent exhibition building in the Russian climate. ${ }^{47}$ Transportability and the dual purpose and second life envisaged for the pavilion were inscribed in every detail of the design. ${ }^{48}$ The technical demands this imposed--requiring a light and portable modular structure that could be at least partly prefabricated in the USSR, shipped and erected in Brussels, and then dismantled and returned home-confirmed the turn to new architectural paradigms.

The unusual aspiration to transport and recycle the pavilion (repeated at the Montreal World Fair in 1967 as Alexander Ortenberg discusses in Chapter XX? demands some explanation. The avoidance of waste had become a key architectural virtue since Khrushchev's 1954 intervention. However, it may have been motivated less by necessity or thrift than by the rediscovery of Constructivist experiments with portable and multifunctional structures and by a commitment to principles identified with destalinization and modernity in contemporary discourse, notably a concern to respect the specificity of architectural types. ${ }^{49}$

A pavilion was, historically, an especially grand and sumptuous tent: a temporary, mobile structure associated, for example, with the military campaign and camp as well as the well as with the fairground. The essence of "pavilionness" consisted in temporariness, portability, transferability. It was a light and open structure that could be erected, dismantled, and re-erected. Designed for natural locations such as gardens or parks, it maintained a close relation with its natural surroundings, between interior and exterior. In contemporary architectural discourse and practice of the Khrushchev era, the tent, a tensile structure consisting of a skin hung from a frame rather than heavy, monolithic, load-bearing walls, represented a counter-model to the massive temple/dolmen paradigm which had underpinned Stalinist architecture, with its aspirations to monumentality and eternity, as exemplified in Boris Iofan's unbuilt prewar design for the Palace of the Soviets (1937) and in the postwar high buildings. 50 
The tent--light and mobile--emerged as the paradigmatic structure of Soviet modernity. ${ }^{51}$ Both the practical demands and the symbolic expression of postwar modernity required light, fluid, portable and temporary structures based on the principle of suspension and tensile strength rather than mass.

\section{Peaceful coexistence at the Brussels Fair}

At the same time, competitors had to take account of another set of considerations: the context in which the USSR's representation of its claims to power and progress would be encountered by visitors to Brussels. The Soviet exhibition organizers and competition brief recognized from the outset both the opportunities and the challenges presented by the juxtaposition of the US and USSR pavilions, as well as by the uneven playing field. ${ }^{52}$ Contiguity compelled the designers to anticipate the comparisons visitors would inevitably draw and the ways in which the other pavilions would orient the shared spaces and vistas. $^{53}$

Not surprisingly, the Soviet organizations involved in planning for the Expo were concerned to find out as much as possible about the plans of other nations, especially their powerful neighbour, the USA. No doubt, the design groups preparing their entries for the competition in summer-autumn 1956 would also have been glad to receive some indication of the American intentions. But information about the American intentions was very hard to glean. A plan of the exposition printed in the architecture journal Arkhitektura SSSR in February 1957 indicated the position of the US section but showed no detail of its footprint (Figure 1). ${ }^{54}$ The US kept its cards close to its chest, whether out of a sense of showmanship, in order to create audience suspense and anticipation, or because internal problems over the planning and funding of the US participation meant that it was behind on the official schedule. 55 The Americans were just as worried about what the Soviets had up their sleeve--particularly after the launch of Sputnik stole their space-race thunder--although they had the advantage that the Belgian organizers allegedly disclosed Soviet plans to them. ${ }^{56}$ It was in the nature of World Fairs that they compelled participating nations to engage in a balancing act between secrecy and publicity, both to arouse curiosity and 
preserve the element of surprise on opening, and to protect trade secrets and technological innovations--all the more so in the climate of Cold War. 57

$<$ Fig. 2: Perspective drawing published in Vasil'ev, "Proekt pavil'ona"

Arkhitektura SSSR, no. 2 (1957): 45. >

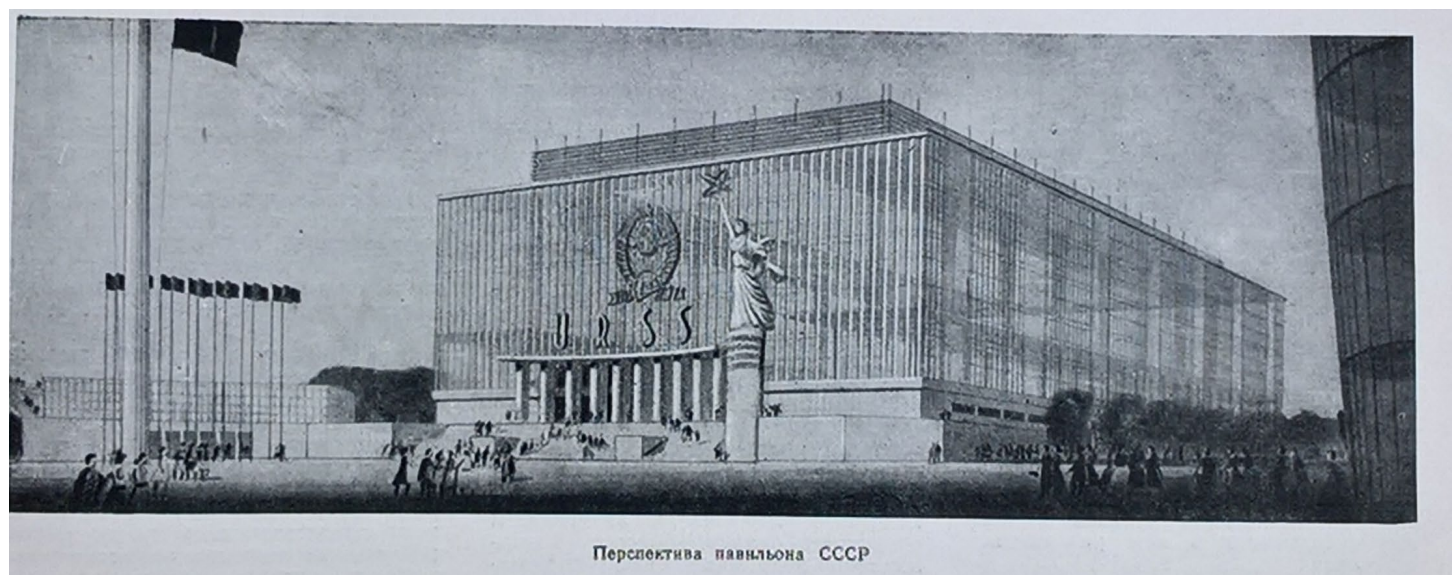

A key question for the Soviet exhibition planners was whether the USA would capitalize on the higher elevation of its site by building a tower to dominate over its Soviet neighbor and mark their aspiration to world supremacy. Towers had a long history at World Fairs as demonstrations of technological progress and engineering's conquest of gravity, as exemplified by the Eiffel Tower. They were also an object of inter-systemic competition. Although the USA had appropriated the skyscraper as a symbol of its capitalist modernity, Soviet architects during the Stalin era had striven to "catch up and overtake" the American conquest of the sky, despite the ideologically antithetical origin of skyscrapers in the property relations of capitalism. ${ }^{58}$ Verticality was a key element in the Stalinist language of power and triumph, exemplified in the unbuilt Palace of Soviets, in the Soviet pavilions for the 1937 and 1939 world fairs and, most recently, as a marker of victory in World War II in the postwar "high buildings".

But whether towers remained an appropriate idiom for Soviet socialism after Stalin had been called in question by Khrushchev's critique of the postwar high buildings with their superfluous and wasteful towers and turrets. The legitimacy of towers was a central part of the question about how to express monumentality and grandeur in a modern, democratic way. The conquest of gravity through advanced engineering and technology, which towers represented, was certainly an achievement the post-Stalin Soviet Union wanted 
to proclaim abroad whether in the form of architecture or of space flight and Sputnik. However, expensive symbolic gestures contradicted the new emphasis on cost-effectiveness and fitness for purpose. An exhibition pavilion required the fluid movement of large numbers of people, as the competition brief demanded, making horizontality preferable to verticality. Moreover, mobility, accessibility, and horizontality were beginning to emerge as symbols of socialist modernity and "democratism". ${ }^{59}$ The heroic conquest of nature could be expressed as much through maximally light, dematerialized tensile structures and gravity-defying roof spans as through monolithic verticality; by looking back to the model of the Crystal Palace rather than Eiffel tower.

Yet, if the USA chose to build a tower, could the Soviet Union leave that gesture of domination unanswered without losing face, seemingly vanquished and supine in America's shadow? By the time the Soviets found out that the Americans were planning "an oval or circular pavilion, close in volume to that of the USSR, and that it would not be a high-rise construction," in November 1956, it was already too late; the Soviet design was already settled and construction begun. ${ }^{60}$ Lacking detailed intelligence in the crucial planning stages, Soviet agencies moved ahead on the basis of informed guesses, speculation, rumor and, above all, a sense of what was appropriate for the new postwar and post-Stalin image of the Soviet Union as a modern, technologically advanced, global power. ${ }^{61}$ Architectural groups set to work on their entries for the competition in anticipation that a neighboring tower would form part of the composition. An elevation drawing of the winning entry by Andrei Boretskii et al. indicates a kind of lattice-work vertical structure, like Trajan's column, looming in the foreground to the right of the Soviet pavilion, in a position corresponding to the US plot. ${ }^{62}$ But rather than answer like with like, Boretskii's design coopted the American gesture into a composition in which the Soviet pavilion was center stage. Balanced on the left of the Soviet entrance by a flagpole, the imagined American tower creates a kind of proscenium arch that frames the vista of the Soviet pavilion. ${ }^{63}$ Reporting on the architecture of other nations' pavilions in September 1956, Boretskii asserted that, in the absence of detailed information, the character of the American and other designs might be guessed from André Waterkeyn's design for the Atomium, "spheres floating in the air," which set the 
keynote, broadcasting its official message of scientific optimism inescapably across the whole exposition. France, for example, was building "an extravagant pavilion, which stands on one point with a cantilevered structure. The design of the USA building is unknown but there are grounds to think that it will be something exceptional." But, Boretskii went on: "We decided that it would not befit us, the Soviet Union, to perform such extravagant tricks, rather we must give a calm, clear and simple architectural solution that is at the same time quite contemporary and fit for competition." 64 The Soviet Union, victor in World War II and leader of the socialist half of the world, should not seek to outdo the capitalist pavilions in virtuoso stunts, but would eschew one-upmanship extravagant gestures and irrational caprices. Although, at a key point in the process, the Soviet designers expected the American pavilion to tower over them, they chose not to compete on these terms. Horizontality was deemed the appropriate expression of modern state socialist power, with its post-Stalin reorientation towards claims of "humanism" and "democratism". The simple rectilinear prism of the Soviet pavilion proposed rationality, classical rigor and dignified restraint as a counterpoise to the American coliseum/circus and French flourishes, although all shared the ideal of weightlessness and simplicity.

A similar line to Boretskii's was taken by Gradov in his authoritative tour d'horizon of "the Brussels architectural festival". Gradov, an influential voice in the Khrushchev reforms of construction and town planning, set up a binary antithesis between socialist architecture and that of the capitalist world. The Soviet and other socialist pavilions were characterized by rationality, clarity, dignity and order. The capitalist ones, by contrast, were marred by irrationality, "contrivance" [narochitost'], individualism, excess, competitive posturing and self-advertising, and "neoformalism," for example in the pavilions of Vatican, France, the Philips pavilion by Le Corbusier, and the Civil Engineering pavilion. 65 Chaos and irrationality (qualities assigned to capitalism), manifested the negative effects of international and private competition, and viscerally exemplified the inferiority of capitalism to the principles of order and rationally planned ensemble (claimed for socialism). The Belgian planning of the exhibition ground as a whole demonstrated the shrill competition for attention that was endemic to capitalist urbanism, which was driven by the interests of commerce, 
advertising, and competition rather than by rational planning in the interests of the greater good of all and of a harmonious ensemble. The difference was most vividly expressed in the contrast between the US and Soviet pavilions. Gradov found, "The USSR pavilion is more monumental and powerful than theirs. Its composition is simple and defined [opredelennaia], and clearly expresses the connection between external appearance and internal space." 66 By contrast, there was "something ostentatious and contradictory" in the USA pavilion, with a taint of "Hollywood superficial prettiness (krasivost')." 67 Thus Gradov aligned the differences of architectural approach to the Cold War antithesis between the two world systems. Dignified restraint and a willingness to engage in dialogue and listen courteously to the other emerge from his account and from Boretskii's statement as principles for a modern socialist form of international architectural engagement, which the USSR pavilion exemplified. Making a virtue of necessity, the decision not to engage in competition with western posturing and flamboyance was recast as a demonstration of Soviet noblesse and cultured maturity.

The winning design for the USSR pavilion: a modern palazzo of grandeur and simplicity

$<$ Fig. 3: Soviet pavilion as built (poss. use the colour sketch by A. Polianskii in Arkhitektura SSSR no. 5 (1958): 32>

Boretskii explained the concept of his group's winning design:

Our solution takes the simplest form of a parallelepiped. Its significance lies in that the whole pavilion is suspended from seven pairs of piers by which an aluminium ceiling, glazed in the central section, is supported by openwork trusses using cables, and from which are hung glass walls. The result is a light and simple construction of glass and metal whose interior space is separated from the exterior space by a corrugated glass wall, allowing visitors outside to look in and see what there is inside the pavilion. ${ }^{68}$

The design was commended by Soviet commentators for its "good architecturalplanning and engineering solution, its successful treatment of the wall planes as a corrugated surface of transparent and semi-transparent glass in combination with light metal; an expressive and original constructive treatment to allow for dismantling, transportation and reassembly." The pavilion aimed to "attract attention by the rigour of its architectural form," by its dimensions (22 metres 
high), by its lightness and elegance, and by "the originality of its construction". 69 That originality, one writer explained to a Soviet mass readership, consisted in the fact that the external walls did not support the roof, but on the contrary, were suspended from it like a tent from its ridgepole, allowing the walls to be no more than a skin constructed of light and delicate materials. The whole building was constructed of steel, aluminium and glass so that it was filled with light and air. ${ }^{70}$ The suspended, tensile structure was expressed on the exterior by the protrusion of the load-bearing piers visible above the parapet of the main roof. In what appears to have been a change from the original plan, the pavilion was erected on site by a Brussels construction company Fernand Gillion using steel produced locally by Ateliers Metallurgiques d'Enghien Saint-Eloi. ${ }^{71}$

Gradov compared the USSR pavilion, characterized by lightness and transparency, to a "crystal palace" or "palace of air." 72 While emphasising its modernity and technological innovation, at the same time he claimed a place for it in the classical tradition of the Parthenon and Ancient Athenian democracy. Calling it "one of the best at the exhibition, reflecting a new stage of Soviet architecture," he praised it for its simple, intelligible composition. It was "a monumental parallelepiped assuredly and majestically mounted on a substructure [plinth] that elevated it slightly above the square, with a wide staircase, spread out hospitably which lends it a democratic character.(...) As in Ancient Greece, many visitors to the exhibition like to make use of these steps to rest, converse, and picnic." 73

Gradov's reference to the architecture of Athenian democracy, likening the pavilion to a modern agora, deserves our attention. The architectural reformers who were influential in persuading Khrushchev to reject Stalinist historicism toward technological modernism, amongst whom Gradov himself was allegedly the most important, had called to reject historicist references in favour of rationality, fitness for purpose and cutting-edge engineering as the drivers of the new architecture and source of its meaning. Yet in the Brussels pavilion the language of classical antiquity was not entirely repudiated; rather it was modernized and its associations with democracy brought to the fore. Indeed a new role was envisaged for classical orders and proportion in contemporary Soviet architecture. ${ }^{74}$ The emphasis on simplicity and grandeur recalled the 
"noble simplicity and quiet grandeur" which Johann Winckelmann (1717-1768) during the enlightenment had identified as the most prominent characteristic of Ancient Greek art. ${ }^{75}$ As Gradov described it, this was a people's palace, conveying the idea of populism or "democratism" through the language of architectural form: transparency, clear logical structure and revelation of its structural principles. Gradov's image of how "the people" spontaneously adopted and made themselves at home in the pavilion was a trope that was also used in other accounts by Soviet authors and Soviet sympathizers. A Belgian poet, in a poem written in response to the Expo, also described the flight of stairs up the entrance of the pavilion as a gesture of inclusion and welcome, a symbol and agent of democracy. "Look how women sit down here, little children play, a greyhaired old man walks. Laughter, songs, voices." 76

While the Soviet commentators above focussed solely on Soviet successes, international reception of the pavilion was divided on ideological grounds. The US design press accused it of lacking courage and innovation, calling it a mere copy, and a bad one at that. ${ }^{77}$ However, ideologically sympathetic commentators on the Expo in the West also picked up on the idea of a democratic people's palace. One author in the Belgian press, wrote that it would be one of the main revelations of the Brussels fair, even though it was insufficiently radical in casting loose from the past: "Of course, one can criticize the gigantism of this palace, made entirely from steel and glass, and one can lament the lack of audacity and originality in Russian architecture, but one cannot deny the quality of what is contained in this palace. It is a panorama of progress achieved by the Soviet Union, especially in the area of industry, since 1917." 78 Another author compared it to a great cathedral, probably with the image of a gravity-defying Gothic cathedral in mind rather than that of a massive post-and-lintel temple. ${ }^{79}$ Alternative designs 


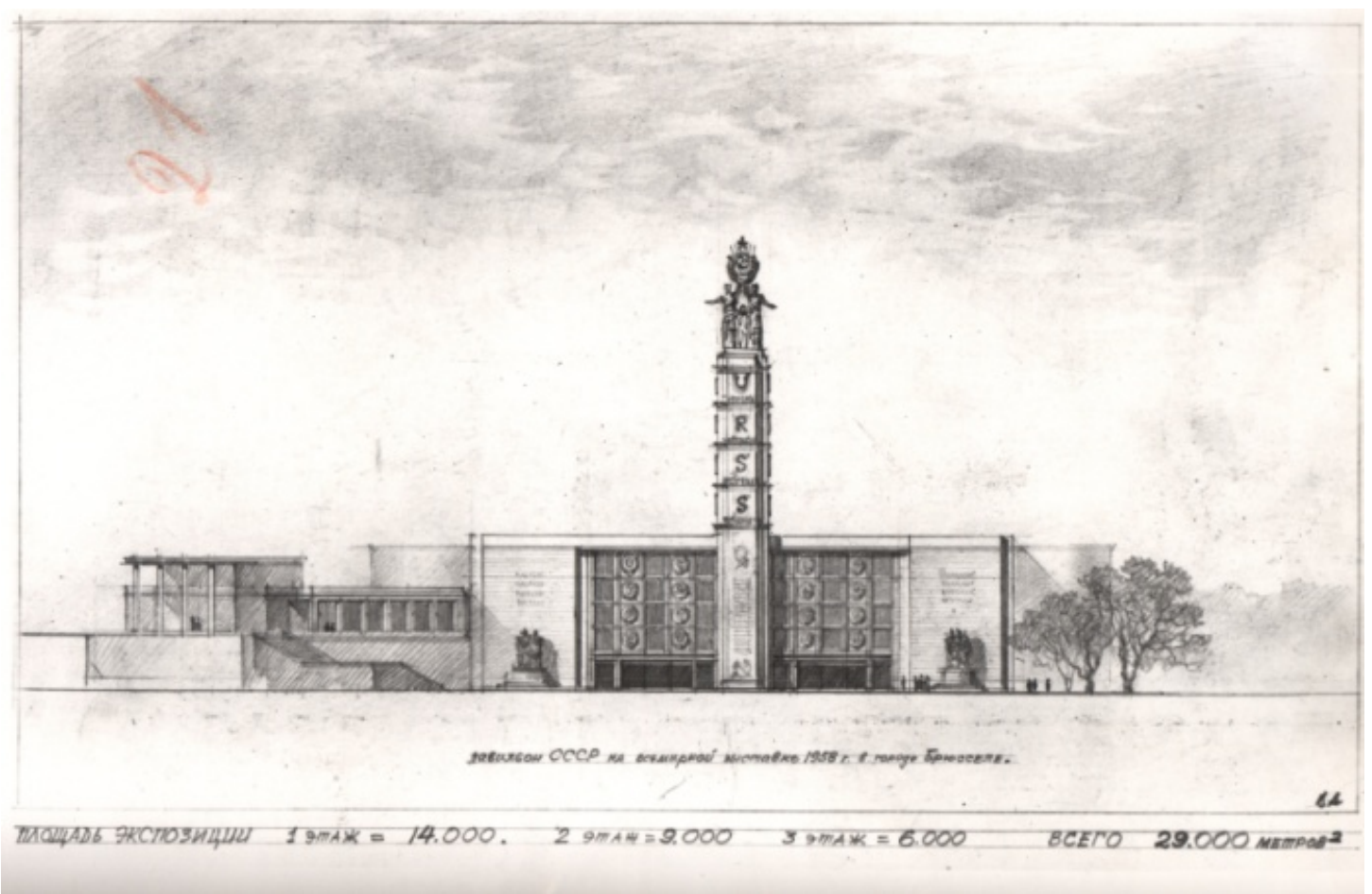

Figure 4: Competition design for elevation of USSR pavilion. GARF f.9470, op. 1 , d. $22,1.21$

The emergence of a new idiom to express Soviet grandeur, power and modernity was not, however, a foregone conclusion in 1956 when the competition for the Brussels design was held. While the winning project and runners up had caught the scent of the new, some competitors still looked backwards for their inspiration, apparently aspiring to invoke and repeat the success of Boris Iofan's pavilion for the Paris World Fair of 1937. In the archives, filed among planning papers for Brussels' 58, is an anonymous drawing of an elevation identified only as "USSR Pavilion at the World Exhibition of 1958 in Brussels". Continuing in the mould of Stalinist verticality, monumentality and obscurity, it is in a quite different idiom from the design that was eventually chosen. It provides a revealing contrast, indicating that the architectural image of the Soviet Union was still a matter of contention between Stalinism and reform, history and modernity. 80

Imposing and archaic, the anonymous design presented blind, ornate walls. Recalling Cohen's binary of transparency and obscurity, these walls appear to be opaque, forbidding the viewer to look in from outside. Continuing in the tradition of the prewar pavilions for the Paris and New York Expos of 1937 and 
1939, as well as of Iofan's 1937 Palace of Soviets design, the elevation is dominated by a central art deco tower, topped by a sculpture group. ${ }^{81}$ However, it lacked the sense of flight and dynamism expressed by Iofan's pavilion, which served as a large forward-thrusting plinth propelling Vera Mukhina's Worker and Collective Farmer into the future (and into confrontation with the National Socialist eagle opposite it on Albert Speer's German pavilion). As in the Stalin-era pavilions and the designs for the Palace of the Soviets, the unidentified architects evidently felt that an "image" was needed to ensure communication of the ideological message; the abstract language of form, structures, technology and materials (or even historical ornament), was not enough. ${ }^{82}$ This contrasts with the winning design by Boretskii et al, which (aside from the crest and lettering "URSS") conveyed its meaning through proportion, transparency, advanced engineering, and the revelation of its structure on the exterior.

$<$ Fig. 5 Iurii Arndt, Lidiia Inber, Evsei Perchenkov, Mikhail Chirkov and engineer Nadezhda Dykhovichnaia, competition entry for Brussels pavilion 1956. Awarded consolation prize. Arkhitektura SSSR, no. 7 (1957): 3>

Like the other entries in the closed competition for the design for the USSR pavilion at Brussels in summer-autumn 1956, the anonymous design was conceived before it was discovered that the USA would not build a tower. But it was already a stylistic anachronism in terms of domestic architectural developments. A faint figure "21" has been handwritten in pencil on the drawing; possibly this was the rank assigned to it in the competition, coming last of the twenty-one entries. Whatever, the results of the competition made clear that this was not the way forward. Blind masonry, towers, occlusion rather than transparency, and the treatment of the building as a pedestal for a sculpture, as if architectural form could not adequately speak for itself, were no longer acceptable means to represent Soviet modernity. ${ }^{83}$

Aside from Boretskii et al.'s winning solution, the GOSSTROI-appointed jury recognized two entries submitted by collectives of young architects to which it awarded consolation prizes. One of these, by Iurii Arndt, Lidiia Inber, Evsei Perchenkov, Mikhail Chirkov and engineer Nadezhda Dykhovichnaia, was a very elegant and simple design, consisting of a low section of a cylinder with a wide central staircase leading up to a glazed façade on which the only detail was the crest of the USSR (barely visible in the drawing, as if the architect were reluctant 
to disrupt the transparency by asserting the materiality of the wall-plane), the letters "USSR" in contemporary sanserif script, and a low, simple portico. ${ }^{84}$

$<$ FIG. 6: Iu. Arndt, design for pavilion of the Permanent Construction Exhibition, Moscow. Arkhitektura SSSR, no. 7 (1957): 3.

Arndt's competition entry suggests that he and his team recognized that the nature of the pavilion's designated resting place in central Moscow also had implications for the design; it was necessary to find a style that would be fit both for the World Fair and for its intended permanent location, amidst Stalinist palaces on Frunze Embankment and in the context of the Construction Exhibition. The Construction Exhibition was also the subject of an architectural competition in 1956, shortly before that for the Brussels pavilion, in which some of the same individuals or teams also competed, including Arndt. ${ }^{85}$ Since the Brussels pavilion, once transported back to Moscow and reassembled, would sit alongside the new pavilion designed for the Construction Exhibition, it is reasonable to assume that architects thought about these two design projects for buildings of the same type--exhibition pavilions--in relation to one another. Arndt et al's design for the Construction Exhibition demonstrated a clear grasp of the new post-Stalin idiom, presenting a single volume affording a vast, low transparent and unencumbered space, with a huge roof span consisting of a low parabolic arch with wings, with a glazed section over the central axis illuminating the exhibits to be shown within. Like a railway station, it allowed function to dictate form. However, it also referenced, in an upscaled and modernized version, the existing pavilion for the Construction Exhibition built c. 1933-34, a low hangar consisting of a segment of a cylinder, with a neoclassical portico placed in front of it. Stripped of ornament to reveal its structure and materials, Arndt's design emphasized horizontality, transparency and simplicity. In the event, the relocation of the USSR pavilion never took place, whether for technical reasons, or possibly because the decision was taken to merge the Construction Exhibition with the All-Union Agricultural Exhibition and the Industrial Exhibition into a single Exhibition of Economic Achievements, which opened in 1959.86 But Arndt et al's design foreshadowed the winning and runner-up entries for Brussels.

\section{Conclusion}


The USSR pavilion for Brussels was the first major statement, in a representative public edifice, of the new approach to construction after Stalin's death. ${ }^{87}$ One of the earliest executed responses to the search for a modern socialist architectural image, it proposed that the new public architecture should express democracy, progress, and "humanism" in terms of big, open spaces, easy access, and transparency, as well as truth to materials and function, horizontality combined with transparency and lightness. Transparency, daylight, and gravity-defying open structures were espoused as architectural metaphors for socialist "democratism" and modernity. This visual identity was worked out and presented both in dialog with domestic paradigms, past and present, and within an international conversation.

1 This paper draws on Susan E. Reid, "The Soviet Pavilion at Brussels '58: Convergence, Conversion, Critical Assimilation, or Transculturation?" Cold War International History Project Working Paper No. 62 (December 2010) <http://www.wilsoncenter.org/topics/pubs/WP62 Reid web V3sm.pdf>, research for which was supported by grants from the Leverhulme Trust and the AHRC.

${ }^{2}$ Frederick Barghoorn, The Soviet Cultural Offensive: the Role of Cultural Diplomacy in Soviet Foreign Policy (Princeton, N.J.: Princeton University Press, 1960), 87; David Caute, The Dancer Defects: The Struggle for Cultural Supremacy During the Cold War (Oxford: Oxford University Press, 2003), 89; Walter Hixson, Parting the Curtain: Propaganda, Culture and the Cold War, 1945-1961 (Houndmills: Macmillan Press, 1997).

${ }_{3}^{3}$ B. Schroeder-Gudehus and D. Cloutier, "Popularizing Science and Ecology during the Cold War: Brussels 1958," in Fair Representations. World's Fairs and the Modern World, ed. R.W. Rydell and N.E. Gwinn (Amsterdam: VU University, 1994), 158 of 157-79.

${ }^{4}$ GARF (State Archive of the Russian Federation) 9518/1/588: 27.

5 Jean-Louis Cohen, "Foreword," in Architecture of Great Expositions 1937-1959: Message of Peace, Images of War, ed. Rika Devos, Alexander Ortenberg and Vladimir Paperny (Farnham: Ashgate, 2015), xxiv.

${ }^{6}$ A US planning document summed up the intended message of the fair: "man, on the threshold of the Atomic Age, may find a better means of achieving human understanding and peace." "Tentative Outline of US Participation in Brussels World Fair" (31 May 1956). National Archives Record Administration, USA (NARA) 306/1011/1.

${ }^{7}$ Susan E. Reid, "Toward a New (Socialist) Realism," in Russian Art and the West, ed. R. Blakesley and S. Reid (De Kalb: Northern Illinois University Press, 2007), 230 of 217-39.

8 On the Brussels Fair see R. Devos, R. and M. de Kooning, L'architecture moderne a l'Expo 58: "Pour un monde plus humain" (Brussels: Fonds Mercator/Dexia 2006); Fredie Floré and Mil de Kooning, "The Representation of Modern 
Domesticity in the Belgian Section of the Brussels World's Fair of 1958," Journal of Design History 16, no. 4 (2003): 320 of 319-40; Schroeder-Gudehus and Cloutier, "Popularizing Science," 157-79; Susan E. Reid "Cold War Cultural Transactions: Designing the USSR for the West at Brussels Expo '58," in Design and Culture 9, no. 2 (2017): 123-45; Catherine Cooke, "Modernity and Realism: Architectural Relations in the Cold War," in Russian Art and the West, ed. R. Blakesley and S. Reid (De Kalb: Northern Illinois University Press, 2007), 172-94; Robert Haddow, Pavilions of Plenty: Exhibiting American Culture Abroad in the 1950s (Washington: Smithsonian Institution Press, 1997); Robert W. Rydell, World of Fairs: The Century of Progress Expositions (Chicago: University of Chicago Press, 1993); Lewis Siegelbaum, "Sputnik Goes to Brussels," Journal of Contemporary History 47, no. 1 (2012): 120-36; Rika Devos, "Let us now invest in peace.' Architecture at Expo 58 in Resonances of War," in Architecture of Great Expositions 1937-1959 ed. R. Devos, A. Ortenberg, and V. Paperny (Aldershot: Ashgate, 2015), 133-160.

${ }^{9}$ Cohen identifies two contradictory strategies in mid-twentieth-century pavilion design: exhibitionism (transparency) and camouflage. Cohen, "Foreword," xxiii.

10 G. Gradov, "Cherty budushchego v arkhitekture Briussel'skoi vystavki 1958 g.," Arkhitektura SSSR, no. 2 (1959): 52 of 48-62.

${ }^{11}$ A. Polianskii and Iu. Ratskevich, "Pavil'on SSSR na Vsemirnoi vystavke $1958 \mathrm{~g}$. v Briussele," Arkhitektura SSSR, no. 5 (1958): 41 of 32-41.

12 Umberto Eco, "A Theory of Expositions," in Faith in Fakes. Travels in Hyperreality (London: Vintage, 1998, 289-307) (first published 1967); Cf.

Marshall McLuhan, Understanding Media: The Extensions of Man (New York:

McGraw Hill, 1964), 7.

13 Polianskii and Ratskevich, "Pavil'on SSSR," 41; Gradov, "Cherty budushchego," 48-62; Rika Devos, "A Cold War Sketch. The Visual Antagonism of the USA vs. the USSR at Expo 58." Revue Belge de Philologie et d'Histoire 87 (2009): 739 of 723-

42; Floré and de Kooning, "Representation of Modern Domesticity," 319-40.

14 Cohen, "Foreword," xxv.

15 Explored in more detail in Reid, "The Soviet Pavilion at Brussels '58"; and Reid, "Cold War Cultural Transactions," 123-45.

16 The principle of Peaceful Coexistence and the "struggle for world peace" were enshrined in the Third Party Program adopted by the CPSU 31 October 1961:

Resolutions and Decisions of the Communist Party of the Soviet Union Vol. 4: The Khrushchev Years, ed. Grey Hodnett (University of Toronto Press, 1974), 204-8.

17 Cooke, "Modernity and Realism," 184.

18 Haddow, Pavilions of Plenty, 95; GARF9470/1/ 1: 6.

19 GARF9470/1/22: 40-41.

${ }^{20}$ Devos, "A Cold War Sketch," 724.

21 "Thematic Treatment: United States Exhibit, Brussels World's Fair 1958,"

NARA306/1011/1; "Policy Guidance for the US Exhibit in Moscow in 1959," NARA306/1050/7; Greg Castillo, Cold War on the Home Front: The Soft Power of Midcentury Design (Minneapolis: University of Minnesota Press, 2010), 139-70.

${ }^{22}$ For further analysis of how the USSR accepted the terms of engagement set by the other side see: Reid, Soviet Pavilion at Brussels '58"; and Reid, "Cold War Cultural Transactions."

23 NARA306/71A2101/159: “US Participation in Brussels 'World Fair' - 1958,” p. 
2. (Emphasis added); Publicity brochure from Office of the U.S. Commissioner General, "The United States Pavilion at the Brussels World's Fair, 1958" (n.d.), NARA306/1011/1; Schroeder-Gudehus and Cloutier, "Popularizing Science," 169-70.

${ }^{24}$ GARF9470 (Materialy sovetskoi sektsii Vsemirnoi vystavki 1958 goda v Briussele)/1/ 22.

25 GARF9470/1/3; GARF9470/1/21.

${ }^{26}$ A. Vasil'ev, "Proekt pavil'ona SSSR na Mezhdunarodnoi vystavke v Briussele," Arkhitektura SSSR, no. 2 (1957): 43-6.

27 GARF9518/1/588: 14; 27 (Report from Zhukov and Ryzhkov dated 4 May 1957); GARF9470/1/21: 162 (Stenographic report of meeting with General Commissar of Soviet Section of 1958 World Fair, 11 May 1957).

${ }^{28}$ GARF9518/1/588: 14; 27 (emphasis added); GARF/9470/1/21: 199 (report by Ryzhkov, 3 Oct. 1957); GARF9518/1/588: 14-15.

${ }^{29}$ GARF9518/1/588: 27.

30 GARF9470/1/3: 41-42; GARF9470/1/27: 127,159-60; GARF9470/1/21: 205.

31 GARF9470/1/22: 13 (Tezisy soobshcheniia Gen. Komissara sovetskoi sektsi o Vsemirnoi vystavke [n.d., c. 1956]).

${ }^{32}$ Khrushchev's hold on power was only confirmed a full year after preparations for Brussels began, in June 1957.

33 "Obrashenie uchastnikov Vsesoiuznogo soveshchaniia stroitelei, arkhitektorov, rabotnikov promyshlennosti stroitel'nykh materialov, stroitel'nogo i dorozhnogo mashinostroeniia, proektnykh i nauchnoissledovatel'skikh organizatsii, sozvannogo TsK KPSS i Sovetom Ministrov SSSR, k vsem rabotnikam stroitel'noi industrii," Arkhitektura SSSR, no. 1 (Jan. 1955), 15; N.S. Khrushchev, O shirokom vnedrenii industrial'nykh metodov, uluchshenii kachestva i snizhenii stoimosti stroitel'stva. Rech'na Vsesoiuznom soveshchanii stroitelei, arkhitektorov, i rabotnikov promyshlennosti stroitel'nykh materialov, stroitel'nogo i dorozhnogo mashinostroeniia, proektnykh i nauchnoissledovatel'skikh organizatsii, 7 dekabria 1954 g. (Moscow: Politizdat, 1955); first published in Pravda, 9 December 1954. English translation, "On the widescale introduction of industrial methods, improving the quality and reducing the cost of construction," in Thomas P. Whitney, ed., Khrushchev Speaks: Selected Speeches, Articles, and Press Conferences, 1949-1961 (Ann Arbor: University of Michigan Press, 1963), 153-92; and in Project Russia 25 (2003): 1217; R. W. Davies, “The Builders' Conference” Soviet Studies 6, No. 4 (Apr. 1955), 443-457.

34 Iurii Gerchuk, personal communication; Adrian Forty, "Cold War Concrete," Constructed Happiness: Domestic Environment in the Cold War Era, ed. Mart Kalm and Ingrid Ruudi (Tallinn: Estonian Academy of Arts, 2005), 44, note 7.

35 Khrushchev, "O shirokom vnedrenii," cited here from Project Russia 25 (2003): 14-15.

${ }^{36}$ E.g. E. Mikulina, "Arkhitektor-stroitel”"; and G. Dukel'skii, "V tvorchestvom sodruzhestve arkhitektorov i stroitelei," both in Arkhitektura SSSR no. 8 (1957). 
37 E.g. Aleksandr Vlasov, "Nazrevshie voprosy sovetskogo zodchestvva," Pravda 28 Sept. 1948, 2; Richard Anderson, Russia: Modern Architectures in History (Reaktion Books 2015), 95.

38 P. Abrosimov, "Tvorcheskie zadachi sovetskoi arkhitektury," Arkhitektura SSSR, 12 (1955), 2-6; P. Abrosimov, "Chetvertyi kongress mezhdunarodnogo soiuza arkhitektorov," Arkhitektura SSSR, no. 10 (1955), 33-35; Cooke, "Modernity and Realism," 179-82.

${ }^{39}$ Khrushchev, O shirokom vnedrenii, 20; [Project Russia, 15; Whitney, 171]; A. Vlasov, "Stil' nashei arkhitektury," Izvestiia, 25 Nov. 1959; Selim O. KhanMagomedov, "Novatorstvo i konservatizm v tvorchestve arkhitektora," Voprosy sovremennoi arkhitektury, no. 1 (1962), 31-48.

40 Abrosimov, "Tvorcheskie zadachi " 2-6; cited in Cooke, "Modernity and Realism," 181.

41 On the 1957-59 Palace of Soviets competition and the Moscow Pioneer Palace see Susan E. Reid, Khrushchev in Wonderland: The Pioneer Palace in Moscow's Lenin Hills, The Carl Beck Papers in Russian and East European Studies Issue 1606 (2002); and Reid, “Khrushchev's Children's Paradise: The Pioneer Palace, Moscow, 1958-1962" in Socialist Spaces: Sites of Everyday Life in the Eastern Bloc, ed. David Crowley and Susan E. Reid (Oxford: Berg, 2002): 141-79. Other projects such as the Kremlin Palace of Congresses and the Rossiia cinema, Moscow, followed in the early 1960s.

42 The USSR Ministry of Construction put forward six projects developed by the Moscow Architectural Studio Glavstroiproekt of Minstroi SSSR; the Institute MOSPROEKT put forward 13 projects; Promstroiproekt and the Vesnin Archtiectural Studio each submitted one project. Vasil'ev, "Proekt pavil'ona," 45. 43 Vasil'ev, "Proekt pavil'ona," 45-46; GARF9470/1/22: 39-40 (Stenogramma soveshchaniia ministerstv i vedomstv, 1 Sept. 1956).

44 Vasil'ev, "Proekt pavil'ona," 46.

45 Ibid, 43; Cooke, "Modernity and Realism," 188; GARF9470/1/16: 102-4; GARF9470/1/22: 13, 39-40.

46 Vasil'ev, "Proekt pavil'ona," 45.

47 All pavilions were to be removed as the Expo organizers' agreement with the city of Brussels committed them to restoring the site to its original state after the fair. GARF9470/1/21: 199-200; GARF9470/1/16: 104; Vasil'ev, "Proekt pavil'ona," 45-6; Polianskii and Ratskevich, "Pavil'on SSSR". Other pavilions were transported and reassembled after the Expo, including that of Czechoslovakia, reassembled in Prague, and of Yugoslavia, rebuilt in a Belgian village, Wevelgem. Cohen, "Foreword," xxvi.

48 To enable it to be transported to Moscow and re-assembled as an exhibition hall in Moscow, the whole structure and its individual elements were designed with dimensions and weight that corresponded to the demands of sea, rail and urban transportation. The load-bearing construction was also designed in accordance with existing Moscow norms at the same time as taking account of the local conditions in Brussels. In the reconstruction in Moscow the external walls would receive secondary glazing heating would be installed. Vasil'ev, "Proekt pavil'ona SSSR," 46.

49 Olga Matich, "Remaking the Bed: Utopia in Daily Life," Laboratory of Dreams: The Russian Avant-Garde and Cultural Experiment, ed. John E. Bowlt, Olga Matich 
(Stanford University Press, 1996), 59-78; Maria Gough, The Artist as Producer: Russian Constructivism in Revolution (University of California Press, 2005); Myroslava Mudrak and Virginia Marquardt, "Environments of Propaganda: Russian and Soviet Expositions and Pavilions in the West," in The Avant-Garde Frontier: Russia Meets the West, 1910-1930, ed. Gail Harrison Roman and Virginia Hagelstein Marquardt. (Gainesville: University Press of Florida, 1992), 65-101. 50 Georgi Borisovski, "Architecture and Technical Progress," Soviet Review 3, no. 2 (1962): 9-10; transl. from Novyi mir, no. 5 (1961).

51 The tent paradigm was adopted explicitly in the Pioneer Palace, Moscow 1958, which was modeled on the idea of a Pioneer camp. See Reid, Khrushchev in Wonderland; and Reid, "Khrushchev's Children's Palace". It was also exemplified in the new buildings designed for the Novyi Artek Pioneer camp on the Black Sea, also by Anatolii Polianskii, 1959-65.

52 GARF9470/1/22: 13; Gradov, "Cherty budushchego," 49.

53 The US pavilion commanded the axis from the Square of Nations. Devos, "Cold War Sketch."

54 General plan of the exposition, Arkhitektura SSSR, no. 2 (1957): 44.

GARF9470/1/22: 64 (Otchet o rabote sektsii arkhitektury i stroitel'stva mezhdunarodnoi vystavki, 21 Nov. 1956); GARF9470/1/21: 200-1.

55 Many other countries were also late; all were waiting and watching to see what the others would do. NARA306/71A 2101/159: "US Participation in Brussels 'World Fair'," p. 4; GARF9470/1/21: 205 (report by Ryzhkov to meeting of Consultative Council under Gen. Commissar of Soviet section, 3 Oct. 1957); GARF9518/1/588: 207. For examples of the kind of information they gleaned: GARF9470/1/25: 76-77 (Materialy Gen. Komissara SShA na Vsemirnoi vystavke 1958 goda, 31 May 1957).

56 Robert C. Hickok, "Comments on Brussels World' Fair," memorandum 8 November 1957, NARA306/1011/1; Schroeder-Gudehus and Cloutier, "Popularizing Science," 157-79.

${ }^{57}$ Rydell, World of Fairs, 208-9; Hixson, Parting the Curtain, 145. Cf. Colomina, "Enclosed by Images," Grey Room 02 (Winter 2001): 6-29. Compare Cohen on the dialectics of "exhibitionism and camouflage": "Foreword," xxiii.

58 Sona Hoisington, "Soviet Schizophrenia and the American Skyscraper," in Russian Art and the West, ed. R. Blakesley and S. Reid (De Kalb: Northern Illinois University Press, 2007), 156-171.

${ }^{59}$ Cf. Vladimir Papernyi, Architecture in the Age of Stalin: Culture Two (Cambridge: Cambridge University Press, 2002).

60 GARF9470/1/22: 64 (Otchet o rabote sektsii arkhitektury i stroitel'stva mezhdunarodnoi vystavki, 21 Nov. 1956); GARF9470/1/25: 74.

${ }^{61}$ Only on 31 May 1957, at a reception dedicated to US participation in the World Fair, did Cullman finally announce any detail about the American pavilion.

GARF9470/1/22: 64 (Otchet o rabote sektsii arkhitektury i stroitel'stva mezhdunarodnoi vystavki, 21 Nov. 1956).

62 Reproduced in Vasil'ev, "Proekt pavil'ona," 45. A color drawing by A.

Polianskii, published a year later (Arkhitektura SSSR, no. 5 (1958): 32 of 32-41)

only shows the flagpole on the left. [Fig. 3] 
63 Cf. Borisovski, "Architecture and Technical Progress.” A similar strategy was used in regard to Stalinist high buildings, the tower of Moscow State University, in the composition of the Pioneer Palace built in Moscow's Lenin Hills, 1958-62. ${ }^{64}$ GARF9470/1/22: 39-40 (Boretskii, 1 Sept. 1956) (emphasis added).

65 Gradov, "Cherty budushchego," 50, 52. The French pavilion, by Guillaume Gillet, was also dismissed in the Western press as an attention-seeking gesture, which "accomplishes nothing that conventional techniques might not have done more economically”. Jane Fiske McCullough, "More Impressions of Expo '58,” Industrial Design 5, no. 8 (1958): 29 of 24-55.

66 Gradov, "Cherty budushchego," 52.

67 Gradov acceded that it was "carried out in spirit of neoclassicism," with a static composition and centrality, and the facades were effective, albeit with a taint of "Hollywood [superficial] prettiness." Ibid.

68 GARF9470/1/22: 39-40.

${ }^{69}$ GARF9470/1/9: 152, 142; Vasil'ev, "Proekt pavil'ona." Contemporary accounts of the pavilion and its structural innovations include: Polianskii and Ratskevich, "Pavil'on SSSR"; A. Polianskii, Iu. Ratskevich, Vsemirnaia vystavka v Briussele, 1958. Pavil'on SSSR (Moscow: Gosstroizdat, 1960); Iu. Ratskevich, "Konstruktsii pavil'ona SSSR na Vsemirnoi vystavke v 1958g. v Briussele," Novaia tekhnika $i$ peredovoi opyt v stroitel'stve, no. 4 (1958): 1-6; I. Nikolaev, N. Mel'nikov, Vsemirnaia vystavka v Briussele 1958. Arkhitektura, konstruktsiia, formy pavil'onov (Moscow, 1963).

70 I. Bol'shakov, Vsemirnyi smotr: uspekh SSR na vsemirnoi vystavke v Briussele (Moscow: Izvestiia, 1959), 12.

${ }^{71}$ Letter from Les Enterprises Générales Fernand Gillion, 30 March 1957. Brussels Archive box 4.11.02; Box 135(provisional numbering system prior to transfer to Belgian National Archives)

72 Gradov “Cherty budushchego," 56.

73 Ibid, 56.

${ }^{74}$ G. Borisovskii, "Klassicheskii order i sovremennost'," Arkhitektura SSSR, no. 3 (1958): pp.

75 Johann Winckelmann, Reflections on the Imitation of Greek Works in Painting and Sculpture) (1755).

76 Charles Muasse, “To Man,” cited in Russian translation in Bol'shakov, Vsemirnyi smotr, 26.

77 McCullough, "More Impressions," 55.

${ }^{78}$ Bol'shakov, Vsemirnyi smotr, 25, citing a newspaper Indépendence (sic: Endepandans).

${ }^{79}$ Ibid, 25, citing an article by Zhan Zherbo (Jean Gerbeau) from Belgian newspaper La Dernière Heure entitled "A Sixth Part of the World in a Cathedral: the USSR Pavilion". Cf. Cooke's eyewitness account in "Modernity and Realism," 189.

80 GARF9470/1/22: 39-40; Vasil'ev, "Proekt pavl'ona,"

${ }^{81}$ Like Mukhina's sculpture group for the Paris 1937 pavilion, this represents a man and a woman, but with the addition of a child between them.

GARF9470/1/22: 21. For detail see Reid, Soviet Pavilion at Brussels '58." 
82 Catherine Cooke, "Socialist Realist Architecture," in Art of the Soviets, ed. Matthew Cullerne Bown and Brandon Taylor (Manchester: Manchester University Press, 1993), 86-105.

83 The tent and no longer the temple was to be the paradigmatic structure of Soviet modernity. Borisovski, "Architecture and Technical Progress."

84 The other was by Sergei Nikulin, Boris Palui (also involved in design of the Pioneer Palace), and Vitalii Pozdniakov.

85 S. Tutuchenko, "Tvorchestvo molodykh arkhitektorov," Arkhitektura SSSR, no. 7 (1957): 3 of 3-5.

86 By a Council of Ministers' Decree no. 591, 28 May 1958, the three All-Union exhibitions--Construction, Agriculture (VSKhV), and Industry--were united into a single Exhibition of National Economic Achievements, the Vystavka dostizhenii narodnogo khoziaistva SSSR. RGAE fonds of RGANTD, Samara, fond 127 (VDNKh) opis 1; fond 887 (Permanent All-Union Construction Exhibition 1933 1958), one opis; fond 27 (Vsesoiuznaia promyshlennaia vystavka VPV) 6 Sept 1955-28 May1958, Opis 1, Introduction; B. Brodskii, "O pokaze dostizhenii narodnogo khoziastva," Dekorativnoe iskusstvo SSSR no. 3 (1959): 28-32. 87 Abrosimov, "Tvorcheskie zadachi," 2-6; cited in Cooke, "Modernity and Realism," 181. 